\title{
Redefining Insurance: Distinguishing Between Life Insurance and Investment Under Volatile Inflation
}

Insurance ${ }^{1}$ has traditionally offered the policyholder guaranteed ${ }^{2}$ benefits contingent on the unpredictable occurrence of a future event. ${ }^{3}$ In contrast, investment arrangements ${ }^{4}$ offer a probability ${ }^{5}$ of increasing, rather than safeguarding, such income. As a result of their different purposes, insurance and investment face different regulatory schemes. The insurance industry is regulated by state agencies, whose chief concern is that insurance companies remain able to satisfy their commitments to policyholders. ${ }^{6}$ In contrast, federal agencies regulate investment activity, seeking to ensure that potential investors are provided with accurate information

1. Insurance reduces the costs of an unexpected event to the individual participant (policyholder) by spreading that cost over the entire group of policyholders. See S. HUEBNER \& K. BLACK, LIFE INSURANCE 2 (9th ed. 1976); P. LAYARD \& A. WALTERS, MICROECONOMIC THEORY 362-65 (1978); see also German Alliance Ins. Co. v. Kansas, 233 U.S. 389, 412-13 (1914) (discussing risk-spreading function of insurance). The word "insurance", as used in this Note, refers to life insurance in the normal "whole life" sense and to annuity contracts. "Whole life" insurance requires the periodic payment of a fixed premium and provides for both a death benefit to beneficiaries named by the policyholder in the event he should die before he is actuarially expected to, and a savings feature that provides the policyholder with a lump sum of money or with an annuity at his retirement. See $1 \mathrm{~J}$. APPLEMAN, INSURANCE LAW AND PRACTICE, \$§ 2-7 (1981). An annuity contract requires a periodic payment of a fixed premium and provides for periodic fixed payments upon the maturity of the contract (usually retirement) made to the annuitant until his death. See S. HUEBNER \& K. BLACK, supra, at 87-97; D. MCGILL, LIFE INSURANCE 81-106 (rev. ed. 1967).

2. The "substitution of certainty for uncertainty" is the very essence of insurance. See S. HUEBNER \& $\mathrm{K}$. BLACK, supra note 1 , at 2.

3. Under life insurance, a policyholder insures a future stream of income for his beneficiaries in the event that his death occurs before it is actuarially expected. Under an annuity contract, a policyholder insures such a stream of income to himself should he live longer than he is actuarially expected to.

4. The Supreme Court defines as the "touchstone" of an investment contract "the presence of . . . a reasonable expectation of profits to be derived from the entrepreneurial or managerial efforts of others." United Housing Found., Inc. v. Forman, 421 U.S. 837, 852 (1975).

5. Investment contracts offer only a potential return, as the investor assumes the risk of failure or success. See A. Alchian \& W. Allen, UnIVERSITY ECONOMICS 473-77 (3d ed. 1972).

6. States assumed reponsibility for the regulation of insurance as early as 1810 . See D. MCGILL, supra note 1 , at 760 . State regulation was upheld by the Supreme Court against commerce clause challenges in Paul v. Virginia, 75 U.S. (8 Wall.) 168 (1868). When the Supreme Court held in United States v. South-Eastern Underwriters Ass'n, 322 U.S. 533 (1944), that the insurance industry was subject to federal antitrust regulation, Congress expressly confirmed state authority over the "business of insurance," even in the context of antitrust law, by passing the McCarran-Ferguson Act of 1945, ch. 20, 59 Stat. 33 (codified at. 15 U.S.C. $\$ \S 1011-1015$ (1976)). See Weller, The McCarranFerguson Act's Antitrust Exemption for Insurance: Language, History and Policy, 1978 DUKE L.J. 587. State authorities also exercise indirect control over premium rates through expense limits and minimum reserve requirements. See $\mathrm{D}$. MCGILL, supra note 1 , at $776 ; \mathrm{S}$. HUEBNER \& K. BLACK, supra note 1 , at $573-74$. 
about the companies and activities in which they may risk their wealth. ${ }^{7}$

Because insurance policies have traditionally paid fixed benefits, ${ }^{8}$ the value of these benefits has declined ${ }^{\theta}$ as inflation has increased. ${ }^{10}$ In recent years, sales of traditional insurance policies have slumped dramatically, ${ }^{11}$ in part as a result of the appearance of a wide variety of investment arrangements promising high and apparently safe yields. ${ }^{12}$

7. The Securities and Exchange Commission (SEC) regulates investments through the 1933 Securities Act, 15 U.S.C. $\$ \S 77 a-77 a a ~(1976)$, the 1934 Securities Exchange Act, 15 U.S.C. §§ $78 \mathrm{a}-78 \mathrm{kk}$ (1976), and the 1940 Investment Company Act, 15 U.S.C. $\$ \S 80 \mathrm{a}-1$ to $80 \mathrm{a}-64$ (1976). The broad purpose of such regulation is:

[T]o prevent further exploitation of the public by the sale of unsound, fraudulent, and worthless securities through misrepresentation; to place adequate and true information before the investor; to protect honest enterprise, seeking capital by honest presentation, against the competition afforded by dishonest securities offered to the public through crooked promotion. . . . S. REP. No. 47, 73d Cong., 1st Sess. 1 (1933).

8. See D. MCGILL, supra note 1 , at 101 .

9. A fixed dollar amount depreciates in value as a result of inflation. See R. BREALEY \& S. MYERS, PRINCIPLES OF CORPORATE FINANCE 86-88 (1981). The Supreme Court recognized this depreciation effect in SEC v. Variable Annuity Ins. Co., 359 U.S. 65, 70 (1959).

10. See infra note 34 .

11. See The Changing Life Insurers, BuS. WK., Sept. 14, 1981, at 66-69 (discussing effects of increased rates of inflation of past three years on insurance industry). For a historical view of the decline in demand for life insurance policies, see Frankel, Variable Annuities, Variable Insurance and Separate Accounts, 51 B.U. L. REV. 177, 179 (1971).

12. These investment arrangements include liquid certificates of deposits, money-market funds, all-savers certificates, mutual funds, and individual retirement accounts (IRAs). IRAs, the newest such arrangement, can be offered by virtually any "responsible financial institution," including both investment and insurance companies. See What the New IRA Rules Do for You, BUS. WK., Sept. 14, 1981, at 122. As any IRA offers the possibility to defer taxes on its accumulation until retirement, a privilege formerly reserved to insurance policies, see infra note 15 , its appearance can be expected to depress further the sale of traditional insurance policies. See IRAs Add a New Dimension to Investing, BUS. WK., Dec. 28, 1981, at 141-42. No limit exists on tax-deferred accumulation through insurance policies, however, in contrast with the IRA. Id. at 142.

The insurance industry has attempted to compete with these high-yielding arrangements by offering similarly attractive yields. Recently, the insurance industry has introduced "universal life" insurance, a policy designed to be an "investment vehicle." The Changing Life Insurers, supra note 11, at 67. "Universal life" was introduced by E.F. Hutton Life Insurance Co. Business Week characterized Hutton's life insurance policy as "more like a tax-free money fund than like life insurance." Id. at 68. Although the IRS has approved E.F. Hutton's product as insurance in a private ruling in 1981, this product could easily be ruled to be an investment. Id. Mutual funds have complained to the IRS about the unfair tax advantages of universal life insurance. Id. at 69.

The IRS recognized the inequities involved with the introduction of universal life and has recently moved to establish criteria that such policies must meet in order to qualify as life insurance for tax purposes. The Tax Equity and Fiscal Responsibility Act of 1982, Pub. L. No. 97-248, sec. 266, 96 Stat. 324,547 (1982), amends I.R.C. $§ 101(f)$ to require that, to qualify as insurance for tax purposes, such policies meet one of the two alternative tests:

(1) The sum of the premiums paid under the contract cannot at any time exceed the greater of the single premium at issue (based on mortality and other changes fixed in the contract and interest at the greater of six percent or the rate guaranteed in the contract) or the sum of the level annual payments over the life of the contract (but not less than 20 years from the issue date, or not later than age 95 , if earlier and computed on the same basis as the single premium except that the interest rate used cannot be less than four percent) necessary to fund the death benefit of the contract and the charges for any qualified additional benefits. Any amount payable on the death of the insured (without regard to any additional benefits) can never be less than 140 percent of the cash value of the contract until the insured reaches age 40 . After the insured reaches age 40, this percentage is reduced (but not below 105 percent) by one percent 
In response, insurance companies have begun offering policies with variable benefits, usually linked to the performance of various equity investments made by the company. ${ }^{13}$ It is questionable, however, whether such policies are in fact insurance policies; to the extent they do not guarantee a specific return, they appear more closely related to investment contracts than to insurance. ${ }^{14}$ By labelling such contracts "insurance," the companies issuing them have benefitted substantially from favorable $\operatorname{tax}^{15}$ and

for each year thereafter.

(2) Alternatively, the cash value cannot at any time exceed the net single premium for the death benefit (without regard to any additional benefits) computed using the most recent mortality tables allowed under all state laws on the date of insurance, an assumed interest rate that is the greater of four percent (three percent for pre-July 1, 1983 contracts) or the minimum rate or rates guranteed in the contract, and a maturity date of not earlier than age 95 .

It is not clear exactly what the insurance industry's response to these alternative tests will be. While their response will clearly be of interest to securities regulators, those regulators have recently announced their own, separate investigation into the problem of characterizing insurance. See infra note 14. This Note provides a clearer test for that examination than the two provided by the I.R.S. (for the limited subset of universal life policies), as it is built around the functional differences between insurance and investments.

The IRS's treatment of "universal life" should be compared with its ruling that the tax-deferred "wrap-around annuity" is taxable as an investment. Rev. Rul. 81-225, 1981-2 C.B. 12. "Wraparound" annuities allow policyholders to "contribute" premium payment to mutual fund portfolios of different risks and expected returns. Policyholders are generally allowed to switch their funds from one portfolio to another as they see fit, while accumulating interest in a tax-deferred account. While the IRS ruled finally that such arrangements are investments, on the ground that policyholders continued to "own" their funds, its ruling came after a long period of uncertainty during which wraparound annuities had become extremely popular. Further, the ruling's rationale was anticipated by companies offering the arrangement. These companies sought to modify their policies to avoid what the ruling accused them of doing. New IRS Probe into 'Wraparound Annuities' Isn't Likely to Stall the Tax-Deferral Plans, Wall St. J., Sept. 21, 1981, at 56, col. 1. The IRS ruling was not expected to delay the introduction of slightly altered policies. IRS Attacks Popular 'Wraparound Annuities,' but Companies Ready New Tax-Deferral Plans, Wall St. J., Sept. 28, 1981, at 56, col. 1.

Finally, if "universal life" is officially permitted by the IRS and SEC, financial experts have predicted that Wall Street brokers will capture up to one-quarter of the insurance market by 1990, The Changing Life Insurers, supra note 11, at 69.

13. For a discussion of recent variable-benefit policies, see The Changing Life Insurers, supra note 11; see also S. HUEBNER \& K. BLACK, supra note I, at 47, 74-78, 93-95 (discussing perceived inadequacies of nominal fixed-dollar annuity payments and life insurance benefits as major factor in development of variable-benefit policies); Frankel, supra note 11, at 177 (same).

14. Recently, the SEC has announced an investigation as to the investment character of a single premium deferred annuity with speculative yields and a nominal minimum guarantee. See Charter Co. Says SEC Probes Need to File Its Single Premium Annuity as a Security, Wall St. J., Nov. 11, 1982 , at 2 , col. 3.

15. Insurance companies are taxed only on that portion of net income not allocable to reserve requirements. Reserve requirements are the amount a company is committed to pay out under its policies. I.R.C. $\S \S 801-805$ (West 1982). Insurance policyholders are not taxed on income from their policies until they receive such benefits. I.R.C. $\$ 72$ (West 1982). Beneficiaries are exempt from tax on benefits received as a result of the insured's death. I.R.C. $\S 101$ (a) (West 1982). The tax-deferred character of the insurance policies further implies that interest on the investment component of such policies accumulates untaxed until the policyholder receives it. These tax advantages reflect a clear policy decision that "life insurance is desirable from an economic and social standpoint as a device to shift and distribute risk of loss from premature death . ..." Helvering v. Le Gierse, 312 U.S. 531, 539 (1941).

Some executives in the insurance industry are concerned that these tax advantages may be jeopardized for all insurance if return-oriented policies such as universal life are seen to undermine the rationale for such advantages. See The Changing Life Insurers, supra note 11, at 68-69 ("If we abuse 
registration ${ }^{16}$ provisions and gained unfair competitive advantages over bona fide investments. At the same time, the unavailability of insurance policies that effectively cover the risk of untimely death by guaranteeing a particular standard of living in times of inflation frustrates the achievement of the goals of security and certainty that insurance traditionally provided.

To curb regulatory abuses and to ensure that insurance continues to serve its traditional functions, investment arrangements posturing as insurance should be regulated as investment, with only genuine insurance regulated as insurance. Fundamental to this proposal is the question of how to distinguish insurance from investment. Although the courts have periodically held particular policies offered by insurance companies to be investment contracts, neither the Supreme Court nor the Securities and Exchange Commission (SEC) has devised a clear test for characterizing any given arrangement as insurance or investment. By analyzing the role insurance plays in our economy, this Note develops one such test, based upon the concept of indexation. This test further suggests an effective response by the life insurance industry to inflation, one that would provide policyholders with the means to secure a future stream of income insulated from either investment or inflationary risk. ${ }^{17}$

\section{The Confusion of Insurance with Investments}

Since the 1950's, the insurance industry has faced pressures arising from the presence of inflation and the popularity of equity-linked invest-

the favorable tax treatment life insurance gets, we stand the chance that we'll lose it.") (quoting George Jordan, Jr., of Great Southern Life Insurance Co.); cf. supra note 12 (discussing recent change in I.R.C. $\$ 101$ (f) regulating universal life insurance more strictly). The tax-deferral feature has been extended to IRAs, which can be offered by virtually any financial institution. Supra note 12 . Unlike life insurance, IRAs limit the amount per year that can be invested. Prospectuses must be filed for IRAs offered by investment companies.

16. Insurance companies and their policies are exempt from SEC registration requirements. Although insurance company executives are grateful to be exempt from all registration requirements, they consider relief from disclosure and regulation under the Investment Company Act as the most important exemption. See Sommers, Fifteen Years of Federal Regulation of Variable Contracts, 32 BUS. LAW. 685, 688-89 (1977). The Supreme Court recognized that the 1940 Act requirements were more burdensome than the disclosure provisions of the $1933 \mathrm{Act}$, and that such burdens implied possible federal-state conflicts. SEG v. United Benefit Life Ins. Co., 387 U.S. 202, 212 (1967) (Harlan, J.); see also Note, Commingled Trust Funds and Variable Annuities: Uniform Federal Regulation of Investment Funds Operated by Banks and Insurance Companics, 82 HARV. L. REV. 435, 462-63 (1968) (discussing but disagreeing with Justice Harlan's concern that placing "heavier burden" of compliance with Investment Company Act might raise conflict between state insurance commissions and federal agencies.)

17. Although this Note concentrates on the definition of insurance for purposes of securities regulation, the test it proposes could be adopted by the IRS for determining the relevant tax treatment of any policy arguably more closely resembling investment than insurance. $C$. supra note 12 (discussing recent changes in the I.R.C. regulating universal life insurance). 
ments. ${ }^{18}$ Its response to these pressures was to offer "variable-benefit" policies that resembled investment contracts. Although the Supreme Court and the SEC recognized the problems associated with variable-benefit policies, the guidelines they designed to distinguish insurance from investment have failed to accomplish their objective. As a consequence, variablebenefit "insurance" policies resembling investment opportunities continue to be offered.

\section{A. The Origin of Variable-Benefit Insurance}

While "insurance" and "investments" are theoretical opposites in both character and purpose, ${ }^{19}$ in practice virtually all insurance policies ${ }^{20}$ exhibit features typically associated with investment. ${ }^{21}$ For example, the traditional life insurance policy, generally referred to as "whole life,"22 and the individual annuity ${ }^{23}$ require premiums that may be divided into "pure insurance"24 and investment components. ${ }^{25}$ Whereas the "pure" portion of the premium pays for the spreading of the specific risk involved, ${ }^{28}$ the investment portion provides the policyholder with a "forced

18. Equity-linked investment arrangements generally convert the contributed money into units or shares of the portfolio by the investment company. The first variable annuities were patterned after such arrangements. See Bartlett, Variable Annuities: Evolution and Analysis, 19 STAN. L. REV. 150, 150-52 (1966); infra p. 1665.

19. The primary purpose of the investment is the enhancement of income. The purpose of insurance, by contrast, is to safeguard a minimum standard of living through securing a contingent source of income. The character of insurance is thus fundamentally risk-averting (or certainty-enhancing); the character of investment is risk-assuming. See Frankel, supra note 11, at 196-99.

20. For a concise summary of the prevalent insurance policies, see R. KEETON, BASIC TEXT ON INSURANCE LAW § 1.3(c), at 13-14 (1971).

21. See 4 L. LOSS, SECURITIES REgULATION 2534 (Supp. 1969). Loss states that the concept of insurance is best described as a continuum, ranging from one-year term insurance (pure insurance) through variable annuities and mutual fund shares to common stocks (pure investment). That insurance companies have offered some investment features without, however, compromising the insurance character of their policies, was recognized as early as 1937, in Daniel v. Life Ins. Co., 102 S.W.2d 256, 260 (Tex. Civ. App. 1937).

22. See supra note 1 .

23. Id.

24. In theoretical terms, the "pure" portion represents the cost to each policyholder of "spreading" the risk insured against. Were administrative costs equal to zero, the "pure" portion would equal "term" coverage in the life insurance context. See $1 \mathrm{~J}$. APPLEMAN, supra note 1, at $\S 4$.

25. This element has also been called the "savings" portion of the insurance policy. See S. HUEBNER \& K. BLACK, supra note 1 , at 66.

26. See supra note 24. The cost of each policyholder's share in spreading this risk is calculated on the basis of actuarial tables. In the life insurance context, such tables establish the expected life for a particular individual as a member of a group of other individuals who are actuarially expected to live a similar number of years. While the use of such group statistics is at the heart of life insurance cost calculations, see S. HUEBNER \& K. BLACK, supra note 1, at 232-38, the practice has been attacked in recent cases when such groupings have been made on the basis of sex. See Brilmayer, Hekeler, Laycock \& Sullivan, Sex Discrimination in Employer-Sponsored Insurance Plans: A Legal and Demographic Analysis, 47 U. CHI. L. REV. 505, 539-41 (1980) (attacking use of race- and sex-segregated actuarial tables) [hercinafter cited as Brilmayer]. 
savings" ${ }^{\text {27 }}$ account. Such investment portions traditionally paid out a guaranteed return. ${ }^{28}$ Not only is this feature a safe form of investment for the policyholder, it also protects the company against the risk of changing mortality rates over the term of the policy ${ }^{29}$ possible losses due to the surrender of policies, ${ }^{30}$ and failure to achieve adequate returns for current commitments. ${ }^{31}$

In the late 1950's, because of the expansion of the American post-war economy, ${ }^{32}$ a generally booming stock market, ${ }^{33}$ and what then seemed to be significant inflation, ${ }^{34}$ insurance companies began to search for methods

27. D. MCGILL, supra note 1, at 57. One popular argument for saving through the investment feature of a life insurance policy is that the policyholder is determined to pay the "protection" element of his insurance policy, regardless of the size of the required premium. He will therefore save additional funds, if that premium includes an investment element, that he might not have had discipline enough to save otherwise. See S. HUEBNER \& K. BLACK, supra note 1, at 24-25.

28. See infra p. 1666; supra note 13 (discussing fixed nominal returns traditionally paid as reason for dissatisfaction in times of inflation); R. KEETON, supra note 20.

29. See S. HUEBNER \& K. BLACK, supra note 1 , at 291 . Such changes in mortality rates have been significant enough to be cited as evidence against the use of sex-based mortality tables. See Brilmayer, supra note 26 , at $551-56$.

30. See S. HuEBNER \& K. BLACK, supra note 1, at 291. A policyholder may wish to surrender his policy if he needs money or believes the money is better allocated elsewhere. In such a case, the insurance company will generally refund the value of the policy's investment portion, less a change designed to reflect the costs of such surrender to the company. If a significant number of surrenders occur, the company may face problems including adverse financial selection, adverse mortality selection, structural changes in the contingency reserves, and additional administrative cost. Id. at 309-10. In the last three years, life insurance policy surrenders, or conversion to purely term insurance coverage, has been described as a "bail-out." See The Changing Life Insurers, supra note 11, at 67-68 (concluding that such policyholder flight has necessitated new policies such as universal life). The conversion from traditional whole-life to term insurance in the meantime has been advocated by a number of financial experts as a means to mitigate loss of value on savings components due to inflation, particularly with the introduction of tax-deferrable IRAs. See IRAs Add a New Dimension to Investing, supra note 12 , at 142 .

31. See S. HUEBNER \& K. BLACK, supra note 1 , at 291 . In committing to pay guaranteed benefits at some future time, insurance companies must place premiums presently collected in investments that will at least meet such future demands. Where an unexpected number of investments fail to be as productive as expected, the additional (uncommitted) yields made from the investment portion of the total premium may aid in paying the guaranteed benefits.

32. National income grew from $\$ 180.3$ billion in 1946 to $\$ 307.7$ billion in 1953 . INT'L FIN. STATISTICS, June 1954, at 172 . Growth in the national income was slightly more subdued during the next ten years, rising to $\$ 481.9$ billion in 1963 , INT'L FIN. STATISTICS, June 1968, at 324 , and rose to $\$ 789.7$ billion by 1968 , INT'L. FIN. STATISTICS, June 1975, at 400 . Inflation during this time was moderate by present standards, see infra note 34 .

33. Industrial share prices (an index of Standard \& Poors for 400 industrial corporations traded on the New York Stock Exchange) rose by more than 100\% from 1953 to 1956, and by over $180 \%$ from 1953 to 1961. INT'L FIN. STATISTICS, June 1962, at 270. Such shares grew more than 100\% from 1958 to 1967, with a slight dip occurring from 1961 to 1962. INT'L FIN. STATISTICS, June 1968, at 324 . For the enormous popularity of equity-based investment arrangements, see Frankel, supra note 11, at 179. Frankel also suggests that the accelerating standard of living in post-war America induced individuals to discover methods of increasing, beyond merely securing, future streams of income in anticipation of future increases in standards of living. Id. at 177.

34. The U.S. cost of living as measured by the International Monetary Fund rose by an average of $11 \%$ per year from 1945 to 1948. Another burst of inflation occurred in 1951 when the cost of living rose by $8 \%$. The cost of living, however, declined slightly between 1948 and 1950. See INT'L FIN. STATISTICS, June 1954, at 172. The cost of living remained stable from 1953 to 1955, but began to climb at an annual average of $2 \%$ after that date. INT'L FIN. STATISTICS, June 1962, at 270. 
to "avoid paying [their policyholders] in depreciated dollars."35 Furthermore, the popularity of equity-linked investment arrangements ${ }^{36}$ offered by mutual funds and commercial banks ${ }^{37}$ threatened lucrative aspects of the insurance business. ${ }^{38}$ In particular, corporate pension plans responded to the widening gap between the yields offered by insurance policies and those offered by funds linked to the stock market. At a time of bullish stock markets and inflation, large corporations were willing to take the moderate risks of "self-insuring"39 in exchange for what seemed to be virtually certain higher returns.

The success of a variable annuity offered by the College Retirement Equities Fund (GREF) prompted imitation by insurance companies. ${ }^{40}$ Under these new policies, net premiums were converted into "units" or shares the value of which was linked to the performance of equity investments made by the insurance companies. ${ }^{41}$ These "insurance" policies thus offered individuals the same equity-linked feature as competing investment arrangements.

Inflation began to rise more sharply in the late 1960's, and increased nearly to $11 \%$ in 1974 . See INT'L FIN. STATISTICS, June 1975, at 400, INT'L FIN. STATISTICS, June 1968, at 324. Although the rate of inflation dropped in 1976, it increased again afterwards, rising to roughly $7.5 \%$ in $1978,11.3 \%$ in $1979,13.5 \%$ in 1980 , and then falling to $9.6 \%$ in 1981. See INT'L FIN. STATISTICS, June 1981, at 408. The Consumer Price Index rose only $3.9 \%$ in 1982. See N.Y. Times, Jan. 22, 1983, at A1, col. 6.

Although the rates of inflation experienced in the 1950's seem moderate by today's standards, the Supreme Court recognized their pressure on the insurance industry in SEG v. Variable Annuity Life Ins. Co., 359 U.S. 65, 70 (1959).

35. 359 U.S. at 70 .

36. See S. HUEBNER \& K. BLACK, supra note 1, at 47 (stating that variable policies were "designed to appeal to the increasing public attraction to equities"); see also Sommers, supra note 16, at 688 (citing insurance industry's lack of equity-linked pension plans as primary reason for loss of business to commercial banks).

37. See, e.g., Frankel, supra note 11, at 179 (discussing intense competition for public's savings, with "enormous" growth of mutual funds and portfolio management services offered by banks through commingled funds); Note, supra note 16, at 436 (linking "phenomenal" growth of mutual funds since World War II with the presence of inflation, and discussing further efforts of banks through bank collective investment accounts to enter mutual fund field).

38. See Sommers, supra note 16, at 688-89. For a confirmation of the importance of corporate pension plans to insurance companies and for comment on Prudential Life Insurance Co.'s success in 1963 in inducing the SEC to exempt group variable annuity plans offered by insurance companies from the Investment Company Act regulations, see Bartlett, supra note 18, at 161-62.

39. Large corporations engage in "self-insurance" when their employees constitute a pool of potential insurance claimants large enough to spread the risk of such claims on an actuarially predictable and therefore financially manageable basis. More simply put, a corporation will "self-insure" when it is able to operate successfully as an insurance company, with its employees as policyholders. See R. KEETON, supra note 20 , at $\S 1.2(\mathrm{~b})(6)$.

40. For a discussion of CREF and the subsequent development of the variable annuity, see Bartlett, supra note 18, at 150-52. CREF's variable annuity was introduced in 1952; by 1962, CREF's assets exceeded $\$ 250$ million. Id. at 152 . CREF encountered virtually no legal problems, in major part because of its special nature as a nonprofit organization catering to a limited clientele of individuals associated with schools and colleges. Id.

41. Id. at 150 . 


\section{B. Variable-Benefit Insurance and the Courts}

State insurance commissioners greeted the new variable-benefit policies with some uncertainty. ${ }^{42}$ Although some states licensed companies offering such policies with little apparent hesitation, ${ }^{43}$ the Connecticut insurance commissioner contended at an early date that the sale of variable-benefit policies was beyond the corporate powers of a life insurance organization. ${ }^{44}$ In Spellacy v. American Life Insurance Association, ${ }^{45}$ the Connecticut Supreme Court agreed. It held that to qualify as an annuity contract, the payments promised had to be a fixed, guaranteed sum. ${ }^{46}$ The guarantee of such a sum constituted the "element of protection which is the very nature of insurance . ..."17

The question of whether an arrangement was insurance or investment was presented in a federal context in SEC v. Variable Annuity Life Insurance $\mathrm{Co}^{48}$ In this case, the $\mathrm{SEC}^{49}$ had sought to enjoin an insurance company from offering its variable-annuity contracts to the public without registering them under the Securities Act or complying with the requirements of the Investment Company Act. The respondent maintained that, because it assumed the policyholder's mortality risk by undertaking to pay the annuity over the duration of the policyholder's retirement, ${ }^{50}$ its policy constituted insurance and not an investment. As such, the respondent argued, its policy was exempt from federal regulation. The Supreme Court disagreed, holding that the assumption of mortality risk was not conclusive:

42. See Bartlett, supra note 18, at 155-56 (many state insurance commissioners assumed jurisdiction over variable annuity but frequently only after states securities commissioners explicitly ceded such jurisdiction); cf. Note, Variable Annuities-SEC Regulation of a Hybrid Under the Investment Company Act of 1940, 19 RUTGERS L. REV. 345, 346 (1965) (referring to initial division of state courts on the insurance character of variable annuities); Morrisey, Dispute over the Variable Annuity, HARV. BUS. REV., Jan.-Feb. 1957, at 75, 77 (describing legislative action in various states on variable annuities).

43. Morrisey, supra note 42, at 77; see also Bartlett, supra note 18 , at 155 (describing minimal state licensing requirements of certain variable-annuity insurance companies after SEC exempted them from Investment Company Act in 1963).

44. See Johnson, The Variable Annuity-Insurance, Investment, or Both?, 48 GEO. L.J. 641, 669 (1960).

45. 144 Conn. 346, 131 A.2d 834 (1957). Spellacy was the only reported state case before the Supreme Court decision in SEC v. Variable Annuity Life Ins. Co., 359 U.S. 65 (1959).

46. 144 Conn. at $355-56,131$ A.2d at 839 .

47. Id. at 356, 131 A.2d at 840. Spellacy was cited by South Carolina's Attorney General in refusing to grant insurance licenses to companies wishing to offer variable annuities in that state. Sec Johnson, supra note 44 , at $670-71$.

48. 359 U.S. 65 (1959).

49. A similar suit brought by the National Association of Securities Dealers, Inc., which was joined with the SEC suit, would seem to indicate that investment companies viewed the development of variable-benefit insurance policies with some wariness.

50. 359 U.S. at 70. 
[T] he concept of "insurance" involves some investment risk-taking on the part of the company. The risk of mortality, assumed here, gives these variable annuities an aspect of insurance. Yet it is apparent, not real; superficial, not substantial. In hard reality the issuer of a variable annuity that has no element of a fixed return assumes no true risk in the insurance sense. It is no answer to say that the risk of declining returns in times of depression is the reciprocal of the fixed-dollar annuitant's risk of loss of purchasing power when prices are high and gain of purchasing power when they are low. We deal with a more conventional concept of risk-bearing when we speak of "insurance." For in common understanding "insurance" involves a guarantee that at least some fraction of the benefits will be payable in fixed amounts.

The Court thus recognized the fundamental role of insurance in replacing uncertainty with certainty, ${ }^{52}$ by requiring that the policyholder be provided with "at least some" ${ }^{36}$ guaranteed level of benefits. It also recognized that the insurance companies faced pressure to provide their policyholders with nondepreciating dollars in times of inflation. ${ }^{54}$ By requiring only that a policy must involve "some investment risk-taking on the part of the company," defining what level of risk-taking by the policyholder would be compatible with "insurance."

The United Benefit Life Insurance Co. subsequently devised a variable annuity contract that generally was believed would satisfy the test devised in the Variable Annuity case. ${ }^{58}$ Under United's "Flexible Fund" contract, the policyholder could, when his contract matured, choose to receive either a proportional share in the performance of the company's investments or a

51. Id. at 71 (emphasis added).

52. S. HUEBNER \& K. BLACK, supra note 1 , at 2 .

53. 359 U.S. at 71.

54. Id. at 70; see also id. at 95-100 (Harlan, J., dissenting) (variable annuity was good faith response by insurance industry to inflation and should be regulated by states rather than federal government).

55. Id. at 71. Justice Brennan's concurring opinion categorized a financial arrangement according to the regulatory concerns to which it gave rise. 359 U.S. at 76 (Brennan, J., concurring). Thus, if a variable-rate policy does not guarantee any particular return or benefit, the traditional state concern for solvency is inappropriate, but the federal concern for disclosure is pertinent. Hence, Brennan would argue, such a policy is investment. The difficulty with this approach is that virtually all policies exhibit features of concern to both federal and state agencies.

56. See Frankel, supra note 11, at 195 (citing Evans, Flexible Fund Annuity and the Securities Act of 1933 and Securities Exchange Act of 1934, in PROCEEDINGS OF THE LEGAL SECTION AMERICAN LIFE CONVENTION 102-03 (1967)). United's "Flexible Fund Annuity" differed from that offered by the Variable Annuity Life Insurance Co. (VALIC) in that the company assumed some minimal investment risk and in that only the accumulation of assets was variable-that is, after the annuity began paying out, such payments were fixed. Id. Like VALIC's policy, however, the value of the annuity at maturity was linked to the performance of the company's stock portfolio. 
life annuity payable in fixed amounts. ${ }^{57}$ In $S E C$ v. United Benefit Life Insurance Co. ${ }^{58}$ the Supreme Court held that this plan was not an insurance contract:

[W] hile the guarantee of cash value based on net premiums reduces substantially the investment risk of the contract holder, the assumption of an investment risk cannot by itself create an insurance provision under the federal definition. The basic difference between a contract which to some degree is insured and a contract of insurance must be recognized. ${ }^{58}$

Beyond indicating that United's guaranteed return was too low and the risk assumed by its policyholders too high, ${ }^{60}$ the Court provided no guidance on what generally distinguished investment from insurance.

In Tcherepnin v. Knight, ${ }^{\text {ex }}$ decided in the same year as United Benefit, the Court held the financial arrangement in question to be a security, thereby triggering SEC regulation. It declined, however, to enumerate any specific characteristics that would generally compel such a determination. Instead, it adopted a "substance over form" test ${ }^{62}$ that required a case-bycase examination. ${ }^{63}$ In retreating from its earlier attempts to distinguish insurance from investment on the relevant bases of risk and guaranteed return, the Court left the insurance industry, regulatory agencies and consumers with little specific guidance. ${ }^{64}$

57. SEC v. United Benefit Life Ins. Co., 387 U.S. 202, 205-06 (1967), rev'g 359 F.2d 619 (D.C. Cir. 1966).

58. 387 U.S. 202 (1967). Note that Justice Harlan wrote the Court's opinion, although he had written the dissent, joined by three other Justices, in the Variable Annuity case. See supra note 54.

59. 387 U.S. at 211 (emphasis added) (citations omitted).

60. See Frankel, supra note 11, at 196 ("The Court did not decide how high the investment risk should be and what methods should be used to cover it in order to qualify the contract as insurance.").

61. 389 U.S. 332 (1967).

62. Id. at 336 ("[I]n searching for the meaning and scope of the word "security" in the Act, form should be disregarded for substance and the emphasis should be on economic reality.").

63. In adopting a test that distinguishes between form and substance, the Court implied that external, easily observable characteristics were an insufficient basis for assessing the regulatory character of ostensibly insurance arrangements. Guidelines for new policies are thus uncertain, as the substance of such policies can only be established after their introduction and marketing. See also infra pp. 1669-70 (discussing Rule 154).

64. Although a number of suits presenting the problem of insurance and investment characterization have been brought since United Benefit, the Court has consistently denied certiorari. Sec, e.g., Grainger v. State Sec. Life Ins. Co., 547 F.2d 303 (5th Cir. 1977) (holding plan to be security), cert. denied, 436 U.S. 932 (1978); Olpin v. Ideal Nat'I Ins. Co., 419 F.2d 1250 (10th Cir. 1969) (plan held to be insurance), cert. denied, 397 U.S. 1074 (1970). In the SEC's amicus brief on the rehearing of Grainger, the SEC could distinguish these two cases only on the grounds that, in the Commission's view, Olpin was "simply decided incorrectly," without pointing to any specific flaw in that decision. See Brief of SEC as Amicus Curiae on Rehearing, at 26 n.42, Grainger v. State Sec. Life Ins. Co., 563 F.2d 215 (5th Cir. 1977), cert. denied, 436 U.S. 932 (1978). 


\section{Variable-Benefit Insurance and the SEC}

Beginning in the mid-1970's, ${ }^{\text {,5 }}$ the SEC sought to draft a rule that would more clearly define the regulatory status of various "guaranteed investment contracts"se offered by insurance companies. The SEC was particularly concerned that such contracts would furnish investors with a vehicle for accumulating tax-deferred income as "insurance," while offering returns (and risks) associated with investment. ${ }^{67}$ The greater the investment character of such arrangements, moreover, the more anxious the SEC was to ensure that investors benefitted from full disclosure under the securities laws. ${ }^{\text {es }}$

The SEC's concerns led it to propose Rule $154 .^{69}$ Paragraph (C) of the proposed rule listed four factors that were to characterize investments: (i) whether the initial term of the contract ends prior to a date on which the purchaser may reasonably expect to elect to begin receiving annuity payments; ${ }^{70}$ (ii) whether the permanent annuity purchase rate guarantee provides for a level of benefits that is substantially less than otherwise commercially available; ${ }^{71}$ (iii) whether the contract provides for determination

65. The SEC's role during the 1960's was less clear. After the Variable Annuity decision, the SEC granted that insurance company a general exemption from the Investment Company Act and then extended this exemption to virtually all companies offering variable-insurance policies to group plans. See Bartlett, supra note 18, at 156-62. For an exhaustive discussion of the significance of SEC exemption in the group plan context, see Frankel, supra note 11, at 234-401. Its exemption was based on the requirement that the companies provide some level of disclosure with respect to the plans offered. However, no clear guidelines were given as to what disclosure was required. One industry expert has characterizd the SEC's involvement after the exemption as virtually nonexistent. See Sommers, supra note 16 , at 687 .

66. SEC Securities Act Release No. 5838 (June 22, 1977), 42 Fed. Reg. 32,861 (1977); see also SEC Securities Act Release No. 6051 (Apr. 5, 1979), 44 Fed. Reg. 21,626 (1979) (discussing SEC's reasons for withdrawing Rule 154).

67. SEC Securities Act Release No. 5838, at 5, 42 Fed. Reg. at 32,862. Note the similarity of the SEC's concern with the purpose of "universal life." The Changing Life Insurers, supra note 11, at 67.

68. SEC Securities Act Release No. 5838, at 2, 5, 42 Fed. Reg. at 32,861-62. The SEC stressed that state regulatory agencies were not suited to "provide the purchasers of those contracts with the protections... which seem necessary and appropriate due to the differences between these contracts and traditional deferred annuity contracts." SEC Securities Act Release No. 5838, at 8, 42 Fed. Reg. at 32,862 . At least in the context of group variable-benefit plans, it had itself failed, however, to give a more precise specification of what these "necessary protections" were to be. See supra note 65 .

69. See SEC Securities Act Release No. 5933, at 13-14 (May 17, 1978), 43 Fed. Reg. 22,053, 22,055 (1978).

70. SEC Securities Act Release No. 5933, at 14, 43 Fed. Reg. at 22,056. This subsection would prohibit insurance companies from offering high and guaranteed nominal rates of return for short periods of time. Even if such rates were fixed, their short duration minimizes the risk to insurance companies that rates will drop and therefore exhibits a primary purpose of investment rather than insurance.

71. SEC Securities Act Release No. 5933, at 14, 43 Fed. Reg. at 22,056. This provision reflects the concern of the Supreme Court in United Benefit that the level of guaranteed benefits and returns for the annuity offered there was "too low." Without defining what a substantially adequate level would be or specifying which mix of provisions other "commercially available" policies offering higher rates should have in common with the challenged plan, however, this provision fails to provide much specific guidance. See supra p. 1668. 
of interest in excess of the guaranteed rate at the discretion of the issuer; ${ }^{72}$ and (iv) whether the contract is marketed as an investment. ${ }^{73}$ Proposed Rule 154 thus focused on the characteristics of insurance that had concerned the Court. As with the Court's efforts, however, these guidelines neither made adequate allowances for the inflationary and market pressures faced by the insurance industry ${ }^{74}$ nor established general standards for distinguishing insurance from investment. ${ }^{75}$ The "tests" proposed by Rule 154 would have required repeated judicial line drawing while giving judges little guidance as to where to draw the line in any particular case.

After receiving largely negative comments from the insurance industry, ${ }^{76}$ the SEC withdrew its proposed rule..$^{77}$ Although the SEC promised continued scrutiny of variable-benefit policies, it has not issued any specific guidelines. ${ }^{78}$

\section{The Present Status of Variable-Benefit Insurance}

While the courts and the SEC have occasionally determined whether certain variable-benefit insurance policies constituted insurance, they have failed to establish an effective test to aid such determinations. As a consequence, the insurance industry has continued to respond to inflation by selling variable-benefit policies that emphasize an equity-linkage feature, thus taking inappropriate advantage of the "insurance" classification to compete against relatively similar investment contracts.

Insurance companies currently market variable-benefit policies that carry potential yields as high as those provided by typical investments. As insurance, such policies have the added benefits of tax-deferral on their yields $^{79}$ and regulation that is far less stringent than that imposed on

72. SEC Securities Act Release No. 5933, at 14, 43 Fed. Reg. at 22,056. The retention of such discretion on the part of the issuer clearly manifests an investment relationship, for the amount of profits the "policyholder" realizes will depend on that issuer's efforts. See supra note 4.

73. SEC Securities Act Release No. 5933, at 14, 43 Fed. Reg. at 22,056. This provision reflects a concern to regulate purported insurance arrangements as investment if they are marketed through advertisement or private representation by promoting attractive after-tax yields. Such a criterion can only be applied on a case-by-case basis, examining the facts of existing arrangements. Perhaps more than any other provision in the proposed rule, this approach fails to provide a general standard capable of consistent guidance to courts, regulatory agencies, and insurance companies. See also supra note 64 (discussing confusion in judicial system resulting from case-by-case approach).

74. See supra p. 1665.

75. See supra notes $62-63,71-73$.

76. Only 1 of the 36 letters responding to proposed Rule 154 favored the proposal. See [1979 Transfer Binder] FED. SEC. L. REP. (CCH) II 82,047, SEC Securities Act Release No. 6050, at 5 (Apr. 5, 1979).

77. 44 Fed. Reg. 21,626 (1979), SEC Release No. 6051 (Apr. 5, 1979).

78. Id.; cf. supra note 14 (announcing SEC investigation in Nov. 1982 of particular annuity policy with investment characteristics).

79. See, e.g., The Changing Life Insurers, supra note 11, at 68 (emphasizing universal life's appeal as chance to "earn a high, tax-free yield"). But see supra note 12 (discussing extension of tax deferral treatment to IRAs and changes in IRS treatment of universal life policies). 
investments. $^{80}$

In spite of their similarity with investment contracts, simply declaring these variable-benefit policies to be investments would be too blunt a response. While such policies resemble investment contracts in many respects, they frequently also fulfill some of the roles of insurance policies. ${ }^{81}$ Regulating these policies as strict investment contracts furthermore would undercut federal policy that insurance be regulated by the states. ${ }^{82}$ In addition, should variable benefit policies be regulated as investments, insurance companies offering such policies as well as other, more conventional, insurance policies would probably need to be regulated as investment companies, under the 1940 Investment Company Act. Such regulation would be costly and might increase the conflict with federalist principles. ${ }^{83}$

\section{A Workable Definition for Insurance}

"Insurance" benefits, paid under annuities and life insurance policies, should be linked to a price index that reflects the cost of living. ${ }^{84}$ Other contracts should be termed "investments" and regulated as such. By requiring that policies be indexed to qualify as insurance, the law would ensure that insurance policies would provide meaningful, "real" coverage to the policyholder and that the policyholder would not shoulder significant investment risk. ${ }^{85}$ Therefore, no need for disclosure to the policyholder, or for other forms of federal securities regulation, would exist.

\section{A. A Price Index-Linked Definition of Insurance}

The need for insurance policies to provide "real" protection against inflation suggests a clear definition of insurance. Any "life insurance policy" not guaranteeing a constant real value of policy benefits should be classified as investment and regulated accordingly. ${ }^{88}$ Insurance companies

80. See supra note 16. What state insurance regulation there is concentrates on ensuring the adequacy of reserves for guaranteed commitments under the policy. Such commitments are minor under a variable benefits policy.

81. Variable-benefit policies have been used for corporate pension plans, where some degree of self-insurance is plausible. In this sense, such policies virtually substitute for mutual fund policies with the principal difference being their exclusion from federal regulation and taxes. See supra notes 38-39. Individuals, whether conscious or not of the investment character of variable plans, undoubtedly rely on such plans for life insurance needs and on balance will in fact receive some life insurance benefits. The uncertainty of the magnitude of such benefits, however, ultimately distinguishes variable benefit from "true" insurance policies.

82. See supra note 6.

83. See supra notes 16,60 (discussing the greater burden that regulation under the Investment Company Act represents as prompting Justice Harlan to remand United Benefit case).

84. See infra note 88.

85. See supra notes $5,19$.

86. This test clearly implies that even "traditional" insurance policies are actually investment arrangements, because their "real" return fluctuates with the rate of inflation. The "real" rate is 
would shoulder the policy's investment risk by guaranteeing the real return offered on the savings component of an insurance policy's contributed premiums ${ }^{87}$ For an annuity policy, both the premiums paid into and the benefits paid out should be fixed in real terms.

The price index should be chosen with particular care. The rationale behind indexation is to preserve the purchasing power of the currently "invested" or "saved" portion of the premium. As consumption patterns change over time, the index may need to be adjusted accordingly. Inflation indices adopted by the United States government, the International Monetary Fund, and the Organization for Economic Cooperation and Development are likely to change over time to reflect these shifts. Insurance companies might elect to adopt such "official" rates, or may wish to define their own index subject to state approval. It seems reasonable to assume that an "official" rate would be perceived as a fair index. ${ }^{88}$

roughly equivalent to the nominal rate minus the rate of inflation. See R. BREALEY \& $S$. MYERS, supra note 9 , at $452-54$. When the rate of inflation fluctuates, therefore, the real return on a policy with fixed nominal rates necessarily will fluctuate as well, violating the proposed test.

That traditional insurance policies are inadequate in the context of inflation is further borne out by the life insurance industry's experience over the last ten years. Because the rate of inflation often exceeded the traditional fixed nominal rate policies (implying a negative real rate of return), many policyholders canceled their life insurance arrangements, either replacing them with variable-benefit policies, see supra note 12 , or with limited "term" insurance, see supra note 30 . By switching to term insurance, policyholders pay smaller ("unloaded") premiums and can presumably place their savings in investments that offer higher potential rates of return. Further, of the presently available insurance policies, term insurance resembles the index-linked policy most closely, because the benefits (if paid out) would be most likely to remain proportional to the contributed premiums. The current success of term insurance thus seems to imply that the public wishes to insure itself, but only on a "real basis." This success should argue in favor of the introduction of index-linked policies. Term insurance currently constitutes $57 \%$ of all new life insurance sales, up from $40 \%$ in 1971. The Changing Life Insurers, supra note 11 , at 68 . Moreover, the policy-lapse rate on whole-life insurance policies has increased to $9 \%$ of all outstanding policies per year. Id. at 66. Policy loans (loans made out of the investment portions of many life insurance contracts at contractually fixed rates) have increased $36 \%$ in the last two years, amounting to nearly $9 \%$ of the life insurance industry's total assets. Id.; see also supra note 30 (discussing financial experts' advice to surrender whole-life and purchase term coverage instead).

87. Insurance companies would be allowed to offer whatever real rate state insurance authorities would permit them, see infra p. 1673. Insurance policies could continue to guarantee the "pure" component of any insurance policy in nominal terms, because that component only buys protection for the period before the next premium is paid. The "pure" component consists of the actuarial cost of sharing the risk of premature death for each policyholder, plus administrative costs. It is roughly equivalent to the term insurance premium. See supra note 24 .

88. It should be pointed out that as inflation affects different consumers differently, no single index is likely to be perfect. For example, to oversimplify, assume that consumers live in either houses or apartments. Where the official price index takes as its price basis for "dwelling" the cost increases in mortgage payments on a typical two-bedroom house, whenever the cost of that mortgage payment increases faster (slower) than the rent for the apartment dwelling consumer, the dweiling cost component in the overall price index will overstate (understate) the change in prices for that consumer. When a shift in the population towards apartment dwelling occurs, it is likely that the official price index will be adjusted to reflect this change. See Blinder, The Consumer Price Index and the Measurement of Recent Infation, 1980 BROOKINGS PAPERS ON ECON. ACTIVITY 539, 548-64. Where such disparities are significant, and to the extent the official index does not adjust adequately for such disparities, indices may be tailored to particular needs, subject to state insurance approval. 
In adopting these fixed real rate requirements, the courts, the SEC, and the insurance companies would have a clearly manageable guideline for the determination of whether a given arrangement is or is not insurance. Moreover, the role of state regulatory agencies in ensuring the ability of insurance companies to pay their liabilities would be restored. . $^{80}$ Such agencies would ascertain whether each company's reserves maintained their value in real terms. ${ }^{90}$

Specifically, each state insurance agency would review the yields offered by insurance policies issued in that state. These yields would have to be guaranteed and linked to the approved price index. The agency would not approve a yield greater than that the insurance company had achieved during the preceding eight quarters. ${ }^{91}$ For example, an insurance company that achieved a return of eight percent during a period of nine percent inflation could guarantee a maximum real rate of return of negative one percent. Future yields on the invested premiums would have to equal or exceed this guaranteed real rate. If a company failed to achieve its guaranteed rate of return, it might be required to lower the yield promised to future policyholders or to disclose publicly its failure to achieve its target rate. ${ }^{82}$

\section{B. Industry Response to the Indexation Approach}

If indexation would solve the investment/insurance characterization problem, why have the insurance companies not offered indexed arrangements, preferring instead to issue variable-rate policies? While the concept of indexed insurance policies has been suggested sporadically since the late 1950 's, ${ }^{93}$ such suggestions have resulted in little commentary.

89. State insurance authorities exercise control over life insurance companies and the policies such companies offer primarily through licensing, expense limits, and minimum reserve requirements. See S. HUEBNER \& K. BLACK, supra note 1, at 573-75. Where variable-benefit policies are offered as insurance, the reserve requirements needed to cover commitments to policyholders will be low, if not altogether insignificant, to reflect the low guarantees made to policyholders under such arrangements. The guaranteed real returns required by the proposed test, by reimposing the investment risk onto the insurance companies would restore the significance of the minimum reserves and therefore the significance of state insurance regulation of those reserves.

90. The actual method of linking benefits to the index selected might include a distributed lag adjustment feature or a moving averages method, which would permit insurance companies to adjust to volatile inflation. For a discussion of several averaging or smoothing features, see E. MANSFIELD, STATISTICS FOR BUSINESS AND ECONOMICS 457-63 (1980). Such methods should be controlled by state regulatory agencies responsible for the solvency of insurance company reserves.

91. The actual time period may vary between states, according to the preferences of state insurance agencies.

92. It should be stressed, however, that the fact that no insurance company would be permitted to promise a real rate of return that it had not already achieved in the past indicates such failure to achieve promised future returns is unlikely. Insurance companies will find it difficult to offer unrealistic yields given this retrospective threshold and the subsequent state checks on returns actually achieved.

93. See, e.g., Bartlett, supra note 18 , at $162-63$ (speculating that index-linked annuity might not 
Perhaps the primary reason that insurance companies have preferred to offer variable-rate policies is that the legal system has allowed them to do so. One life insurance authority has noted:

During the preceding decade [1957-1967], the life insurance business had been studying its products from the standpoint of their attractiveness to the public in the light of economic trends and prospects. Out of this process of self-examination have come changes in product design to adapt life insurance to our modern economy. The most notable, of course, were those designed to appeal to the increasing public attraction to equities. . . . In an industry so bound by statute and public regulation, and so conscious of and conscientious about its public trust, it was inevitable that change in product design and in marketing concepts would be evolutionary rather than revolutionary. ${ }^{94}$

Yet such "evolutionary" change has not only thrown the existing federal/state system of regulation into confusion, but it has also failed to maintain a healthy demand for life insurance policies. ${ }^{95}$ In the absence of a clear lead from the courts or regulatory agencies along lines proposed here, then, it seems likely that the insurance industry will continue to "muddle through" by offering policies that closely resemble investment contracts. $^{.68}$

Industry inertia is not only induced by the failure of the law to provide a clear lead, but also reflects the traditionally staid investment experience of the insurance industry. Insurance companies have traditionally matched revenues with similarly maturing policy commitments while "locking in" the differential as profit. ${ }^{27}$ The return on the life insurance industry's investments has been relatively low over the past ten to twenty years, ${ }^{98}$ in

be "implausible," satisfying more directly the need variable annuity "professes to meet"); Johnson, supra note 44, at 661 (referring to "cost-of-living" annuity plan offered by National Airlines to its employees, with benefits linked to United States Labor Department's Cost of Living Index); BUS. WK., Nov. 23, 1968, at 126 (discussing index-linked annuity offered by Occidental Life Insurance Co. as new effort in "search for a hedge against inflation").

Indexation of a special type exists for certain home insurance policies, such as Allstate's "Replacement Cost" insurance (providing for replacement of home in case of destruction, through indexation of original house's valuation to an index of construction costs). Finally, Richard Pratt, current chairman of the Federal Home Loan Bank Board, has supported a proposal by the savings and loan industry to link the IRA rate to rates paid on Treasury securities. Wash. Post, Nov. 21, 1981, at A2, col. 1. Such a proposal indicates that other industries are considering indexation as a means to provide traditional functions, in this case, safely increasing the value of individual savings.

94. S. HUEBNER \& K. BLACK, supra note 1 , at 47.

95. See supra notes 11,86 .

96. The present trend to "universal life" is clear evidence of this inclination. See supra note 12.

97. See S. HUEBNER \& K. BLACK, supra note 1, at 42 (discussing extent of matching policy commitments with maturing mortgages and corporate bonds).

98. Life insurance companies earned roughly $8 \%$ on nearly $\$ 500$ billion in investments in 1980 , see The Changing Life Insurers, supra note 11 , at 66 , while inflation equalled roughly $13.5 \%$, see 
part as result of the large sums the industry has invested in fixed-rate, long term corporate debt. ${ }^{90}$ The same inflation and economic growth that led to the introduction of variable-rate policies to investors, however, severely diminished the profitability of the companies' fixed-rate investments. Rather than change its investment policy, the insurance industry sought to shift the investment risk on to its policyholders.

The recent emergence of index-linked corporate bonds ${ }^{100}$ greatly eases the difficulties of offering indexed insurance policies by providing insurance companies with an investment vehicle that allows them to match index-linked disbursements with index-linked revenues. Furthermore, insurance companies have already started searching out investments that generate price-linked returns. For example, they have greatly increased their ownership of commercial real estate, leasing such real estate with escalator provisions adjusting rental payments due. ${ }^{101}$ In lending to corporations, insurance companies are increasingly demanding provisions allowing interest rates to adjust to market changes or permitting conversion of the debt into equity, and are choosing shorter maturities. ${ }^{102}$ Thus, it seems likely that the proposed change in the definition of insurance would prompt the insurance industry to supply index-linked policies. Given current public awareness of the threat inflation poses to long-term savings, ${ }^{103}$ an active market for such policies could be expected to develop.

supra note 35. This low rate of earnings is calculated over all assets, including long-term bonds purchased many years ago. Id. at 69. The American Council of Life Insurance (ACLI) has estimated returns on insurance company investments as $4.11 \%$ in $1960,4.61 \%$ in $1965,5.34 \%$ in 1970 , and $6.44 \%$ in 1975 , with such returns rising each year. AMERICAN COUNCIL OF LIFE INSURANCE, LIFE INSURANCE FACT BOOK 61 (1979).

99. "Life insurers currently hold one-third of the approximately $\$ 500$ billion of outstanding U.S. corporate debt (not counting mortgages)." The Changing Life Insurers, supra note 11, at 66. Corporate debt represented approximately $36.7 \%$ of all life insurance assets at the end of 1974. S. HUEBNER \& K. BLACK, supra note 1 , at 524 . Corporate and government bonds, and mortgages constituted $76 \%$ of the insurance industry's new investments in 1978. This ratio has declined to $44 \%$ as a result of changes in investment strategy. The Changing Life Insurers, supra note 11, at 66.

100. See White, Next in Corporate Finance: Index-Linked Loans?, HARV. BUS. REV., Sept.-Oct. 1981 , at 14 (discussing factors likely to result in increased availability of such corporate paper). Given the volume of insurance company lending to corporations, the expansion of such bonds is virtually certain to follow the indexation of insurance benefits, thereby enabling insurance companies to match again the maturities of their (index-linked) debt with their (index-linked) policy commitments.

101. See The Changing Life Insurers, supra note 11, at 69-71.

102. Id. at 66 .

103. For recent articles in popular magazines indicating and contributing to the public's awareness of inflation, see Harris, Simple Secrets to Beat Inflation, READER's DIG., Jan. 1981, at 161; How to Inflation-Proof Your Marriage, LADIES' HOME J., July 1980, at 81 . Some polls suggest the possibility that the public may prefer an offer of real rates to the corresponding nominal rate. See Citizens Find Inflation Worse than Reported, NATION'S BUS., May 1980, at 81 (indicating public's distrust of nominal prices); Reagan's Top Problem: Braking Inflationary Expectations, Bus. WK., Dec. 1, 1980, at 104-06. 


\section{Advantages of an Index-Linked Definition of Insurance}

The use of an index-linked definition of insurance would be a major step toward resolving the continuing regulatory confusion discussed in this Note. Further, by redirecting the insurance industry to its traditional certainty-enhancing function, it would also tend to promote interindustry equity and market efficiency.

Variable-benefit policies, including the current popular "universal life insurance" policy, compete for the public's investment dollars against investment arrangements such as mutual funds and commercial bank collective investment accounts. ${ }^{104}$ Like those arrangements, these "insurance policies" often emphasize potentially high returns, but are uniquely aided by tax and security regulations advantages because of their "insurance" status. ${ }^{105}$ The index-linked test effectively limits the use of these regulatory advantages to policies that emphasize features important to traditional insurance concerns, namely, reliable, guaranteed returns that secure to the policyholder a certain minimum standard of living, even during inflationary periods. Consequently, different regulatory treatment would no longer be inequitable. ${ }^{108}$

If, as expected, ${ }^{107}$ the institution of the index-linked tests leads to the introduction of index-linked insurance policies, it seems likely that consumer efficiency would be enhanced. In the absence of such "certaintyenhancing" policies, especially in the context of inflation, consumers would tend to substitute for such coverage in an imperfect and costly manner. ${ }^{108}$ The introduction of index-linked policies would limit such inefficiency. ${ }^{109}$

104. See supra notes 12,37 .

105. See Frankel, supra note 11, at 224 ("A mutual fund is not permitted to avoid federal regulation by purchasing life insurance policies and attaching them to its shares. By the same token, an insurance company should not avoid federal regulation merely because it sells mutual fund shares in conjunction with an insurance policy."); see also Note, supra note 16 , at 468 (concluding that variable annuities should be subjected to same regulation as mutual funds and commercial bank collective investment accounts). For a discussion of unfair tax advantages and the recent IRS response, see supra note 12.

106. Given that minimum reserve requirements will be significant for policies meeting the proposed test, supra note 89 , and that state insurance agencies will have greater control over the rates of return insurance companies offer potential policyholders (subject to the company's past returns, see supra p. 1673), state insurance regulation will be more meaningful than it currently is. With this change, moreover, any comparison of relative regulatory burdens between investment and insurance becomes more ambiguous.

107. See supra p. 1675.

108. See Lancaster, Socially Optimal Product Differentiation, 65 AM. ECON. REV. 567 (1975).

109. The introduction of a certain-value contingent commodity such as index-linked life insurance would seem to satisfy a basic condition for a stable neoclassical economic equilibrium. See E. WEINTRAUB, MICROFOUNDATIONS 27-35 (1979). Note, however, the problems of the second best presented here, and problems in general with static equilibrium models in economics. Id. at 35-37. For an introduction to the theoretical importance of perfect insurance markets, see P. LAYARD \& A. WALTERS, supra note 1 , at $376-82$. 
Finally, life insurance companies are comparatively much more capable of adjusting to economic change than are their policyholders. Indeed, given their actuarial experience, their strong influence on corporate lending practices and their traditional freedom from the pressure to sell on a quick commission basis, ${ }^{110}$ insurance companies may be uniquely suited to provide "real" protection against inflation.

\section{Conclusion}

In tinkering with variable-benefit policies, the insurance industry and its regulators seem to have ignored the fundamental purpose of insurance and of its corresponding regulatory framework. By applying the test proposed in this Note, ${ }^{111}$ the courts and regulatory agencies would both restore order to the existing regulatory framework and induce the insurance industry to offer policies that provide adequate protection in times of volatile inflation.

110. See The Changing Life Insurers, supra note 11, at 69 (discussing hesitancy of investment brokers to sell traditional insurance policies in part due to time required to make sale to inquisitive potential policyholders).

111. The test should be applied prospectively. Current arrangements not meeting the requirements for insurance should be permitted a grace period of six months to one year in which to adjust variable-benefit policies to full insurance. The conversion of committed assets, presently allocated to "policyholders" by shares or units, see supra note 18 , to commitments valued in monetary terms should not present any difficulties, as such conversion takes places whenever a variable-benefit policy is surrendered or matures. 